placements from an underground fracture (M. Mitra); waves in anisotropic media (K. R. Nag, M. L. Gogna); surface waves in inhomogeneous media (T. N. Maulik, Kehar Singh); Love waves in media with non-planar boundaries (P. Avtar); transverse waves in hypoelastic media (P. D. S. Varma); leaking modes (S. D. Chopra); seismometer arrays (A. R. Bhangar); surface seismic waves recorded at Delhi (H. M. Chaudhry); applications to oil exploration (Prem Prakash); standard seismograph network in India (A. N. Tandon).

\section{Non-destructive Testing of Steel Castings}

THE booklet Recommended Procedure for the Ultrasonic Examination of Steel Castings was prepared by the Nondestructive Testing Panel of the British Steel Castings Research Association, under the chairmanship of Dr. L. G. Finch (Hatfields Ltd.) (Pp. vi +49. Sheffield: The British Steel Castings Research Association, 1964. 30s.) It deals with the testing of the most ferritic castings of carbon and alloy steels, but not with austenitic alloys. The surface contact method of examination is discussed and recommended as an aid to quality control. It may also be applied to the measurement of casting thickness. A casting should be heat-treated before carrying out the ultrasonic examination. A pulse type of ultrasonic flow detector, preferably covering the frequency range of 0.5 $5 \mathrm{Mc} / \mathrm{s}$, is recommended and its performance in relation to certain simple tests covering sensitivity, penetration power and resolution is discussed in some detail in an appendix to the booklet. The advantages of three specific types of ultrasonic transducers (probes) are described both in the text and in a separate appendix where the basic features of ultrasonic waves and their production are outlined. Adequate transmission of the ultrasonic energy between the probe and the casting nocessitates the use of a couplant. The limitations of the procedure are clearly stated, together with the form that test data and records should take. The booklet includes a glossary of terms used in the ultrasonic examination of steel castings, but it is expected that a British Standard covering a larger number of terms will be published later.

\section{A Soil and Irrigability Survey in Swaziland}

UNDeR the auspices of the Department of Technical Co-operation, an area of 352 square miles, in the Lowveld and lying to the south of the lower Usutu Basin, has been surveyed to see how far irrigation might be successfully practised to increase crop production (Overseas Research Publication No. 3. A Soil and Irrigability Survey of the Lower Utusu Basin (South) in the Swaziland Lowveld. By C. Murdoch and J. P. Andriesse. Pp. iv +181 . London: H.M.S.O. 25s. net). At present, the growing of maize, cotton, sorghum, tobacco and beans is precarious on account of the uncertainty of sufficient summer rainfall. The total rainfall is about 30 in., but this falls very short of the estimated evapotranspiration, and water resources are mainly from the rivers, the water-table usually being at great depth. Differences in natural vegetation arising from climate, topography and soil, particularly permeability and drainage, are difficult to assess on account of past burning, grazing and cultivation. Shifting cultivation is the usual system of agriculture and involves cropping for 2-6 summers followed by reversion to bush for 10-15 years. The average crop of maize is only some $300 \mathrm{lb}$. per acre, which is inadequate for the population. The 40 soil series identified are grouped into 16 mapping units based on morphology. These are described and compared and the effects of human activities discussed with respect to erosion and impoverishment. The variables affecting irrigability are evaluated and irrigable classes are defined and their distribution in the area specified. Only small scattered portions of the area are suitable for general purpose irrigation, but about 4,000-6,000 acres might be irrigated without much difficulty by pumping from the Usutu River; there are also tracts of soils that are not permeable or are shallow but where irrigation for special crops, such as rice or pasture, is feasible. There is a list of references, 3 appendixes comprising flora, vocabulary and index of authors, and 2 sheets of maps.

\section{New Marsupials}

Barrow IsLaND, off the north-west coast of Western Australia, is inhabited by a number of unusual species of marsupials and other Australian wild life. When the company testing for oil became aware of the value of this fauna to naturalists great care was taken to ensure that the animals were not interfered with or disturbed. The situation is described in the South African Journal of Science $(60$, No. 11, 1964). The animals include a wallaby which grows to a length of about $4 \mathrm{ft}$., and is closely related to the Euro, or roan wallaroo, a hopping marsupial found on adjacent islands. There is also a 'spectacled' hare-wallaby, which has orange rings round its eyes, and a rat-kangaroo about the size of a domestic eat, which is exclusive to the Island. The latter is being studied at the American Museum of Natural History and the Western Australian Museum. A small marsupial mouse, some. what similar to the species that exists in the McDonnell Ranges, in central Australia, a bandicoot which may represent a new species, and a water rat, about 12 in. long, with a beautiful fur, have also been found.

\section{Insect Sounds}

Moss insect 'songs' are known to be produced by the rubbing of one part of the body against another, for example, a row of 'teeth' in the form of a comb or file engaged by an opposing 'edge' or 'scraper'. In the case of field crickets both file and scraper are borne on the forewings; but although each forewing bears both file and scraper, the functional file is normally on the ventral side of the right wing, the scraper on the dorsal inner margin of the left wing. "During stridulation the forewings are held at an elevation of about $45^{\circ}$ and vibrated rapidly, with the scraper engaging the file teeth on each downstroke. As each file tooth is struck by the scraper, opposite thrusts are imparted to file-tooth and scraper and a sound-wave is created in the air." These and other interesting facts of insect sounds emerge from much recent research on this subject; a particularly informative paper entitled "Song Differences in Closely Related Cricket Species and Their Significance", by R. S. Bigelow, Depart. ment of Zoology, University of Canterbury, Christchurch, New Zealand, has recently been published (The Australian Journal of Science, 27, No. 4; October 1964). The author quotes R. D. Alexander: ". . . the usual male cricket has the only stridulatory device known which produces a 'pure' frequency-a sound reproduced as a sine wave on an oscillograph and sometimes exceeding 100 decibels at its source". But apart from frequency, cricket songs contain other components which must be fully understood before detailed interspecific song comparisons can be attempted. Experiments with magnetic tape-recordings of cricket songs have proved successful; it is shown that if such a tape is passed through very fine iron filings, the iron adheres to the magnetized bands on the tape and the song components can then be analysed and visually measured by the 'ferrographs' thus produced, of which examples are given. The paper also discusses cricket hearing, song patterns, and inheritance of song patterns. Some interesting conclusions are reached: "The significance of song differences between closely related cricket species lies primarily in the fact that they are, as a direct result of their function in the prevention of interspecific gene exchange, the best possible taxonomic character for discrimination between cricket species in the field". Also, "Communication between field crickets through song signals is one of the best known, and most efficient. 